\title{
Financial Intermediation and Economic Growth in Saudi Arabia: An Empirical Analysis, 1968-2010
}

\author{
Hatim Ameer Mahran ${ }^{1,2}$ \\ ${ }^{1}$ Department of Economics, Imam Muhammad Ibn Saud Islamic University, Riyadh, Saudi Arabia \\ ${ }^{2}$ Department of Economics, University of Gezira, Wad Medani, Sudan \\ Email: mahranec@yahoo.com
}

Received June 9, 2012; revised July 8, 2012; accepted July 16, 2012

\begin{abstract}
Long-term sustainable economic growth is manifested in high rates of physical and human capital accumulation. It depends on the ability of the economy to mobilize financial resources, and to ensure access by people to these productive assets, which should be invested more efficiently. This process summarizes the role that financial institutions have played in financial intermediation and growth, namely to mobilize savings and allocate them to the most productive and growth-promoting activities. The core argument is that greater financial intermediation gives rise to higher productivity and thus higher national and/or per capita income. This paper examined the empirical relationship between economic growth and financial intermediation for Saudi Arabia during the last four decades (1968-2010). To this end, we adopt the autoregressive distributed lag (ARDL) methods to cointegration and the associated error correction model (ECM). Despite the minimal restrictions imposed on the functioning of the domestic financial system with a view to "fighting terrorism", the results overwhelmingly indicate that financial intermediation has impacted negatively on long-run real GDP. These findings are attributed to two sets of factors relating to the dominance of economic activities by the public sector and the characteristics of the institutional environment surrounding the private sector, as well as to some functional and structural characteristics of the financial system that have impeded its development.
\end{abstract}

Keywords: Long Run Growth; Financial Intermediation; Cointegration; ARDL Model; Error Correction Model

\section{Introduction}

Long-term sustainable economic growth is manifested in high rates of physical and human capital accumulation. It depends on the ability of the economy to mobilize financial resources, and to ensure easy access by investors to these productive assets and their allocation to the most efficient and productive uses. Thus, over the past decade, considerable attention has been attached to the role of financial intermediation on economic growth. The financial sector plays this role mainly by mobilizing domestic and foreign savings for investment and by providing liquidity to firms and ensuring its allocation to the most productive and efficient activities. This is the historical role that banks and non-bank financial institutions (ranging from pension funds to stock markets) have played in financial intermediation, by translating household savings into enterprise investment, monitoring investments, and spreading risk ${ }^{1}$.

\footnotetext{
${ }^{1}$ Although financial intermediation has strong positive externalities resulting from such services as liquidity and information provision, it can also have negative externalities resulting from bankruptcy, non-performing loans, and financial crises; these have more recently become endemic to market systems.
}

Although the relationship between financial development ${ }^{2}$ and economic growth has occupied the minds of economists from Smith to Schumpeter, both the channels and direction of causality have remained unresolved in both theory and empirics. Most empirical studies (e.g. [1-3]) concluded that development of the financial sector accelerates economic growth. However, for a number of reasons, the link between financial sector development and economic growth in developing countries might well be ambiguous. First, most investment in these countries takes the form of foreign direct investment, which replaced domestic financing. Second, because of deficiency in bank deposits, bank credit to the private sector has been considerably low. Third, because financial development in most countries was accompanied by structural institutional changes, it becomes very hard to separate the impact of each on economic growth.

The wide range of organizational forms involved precluded any clear conclusion as to what kind of financial

\footnotetext{
${ }^{2}$ While financial development is sometimes treated as being synonymous with financial intermediation, it also involves the establishment and expansion of institutions, instruments and markets that support the growth process.
} 
institutions might maximize economic growth. Nevertheless strong causality from particular organizational forms of financial institutions to economic growth has recently become a central axiom of economic theory. This is further strengthened by the evidence from cross-country studies of the relationship between indicators of financial development and observed rates of growth. The core argument is summarized by two main conclusions. First, greater financial depth measured by higher total financial assets/ national income (output) ratio is associated with higher levels of productivity and economic growth. Second, higher levels of productivity and economic growth are also associated with a more advanced financial structure (i.e. the switch from banks to nonbank financial intermediaries, and from both of these to stock markets).

In the post-war decades, developing countries adopted the traditional development finance model based on the banking system, bank finance, directed credit, public development (specialized) banks, closed capital accounts, capped interest rates, and active monetary interventions. Dismantling this model has become a core element of the economic reform and structural adjustment process led by the international financial institutions. The new standard model of financial structure reflects the imperatives of "financial development" based both on research in developing countries and the concurrent process of financial market liberalization adopted in the advanced economies which moved away from national bank-based systems towards open capital markets. These reforms were expected to raise savings and investment levels, increase the rate of growth and reduce macroeconomic instability. However, it is doubtful whether these objectives have been achieved. Most cited in this respect is the series of financial crises that have erupted since the mid-1990s and the decline of funding for large firms in productive sectors, and SMEs in general, which are probably more significant for sustainable growth and poverty reduction in the long run.

Motivated by the recent economic diversification and liberalization measures, this paper examined the empirical relationship between economic growth and financial intermediation for Saudi Arabia during the last four decades (1968-2010). Autoregressive distributed lag (ARDL) methods to cointegration and the associated error correction model $(E C M)$ are adopted in the analysis. The results overwhelmingly indicate that financial development has impacted negatively on the long-run level of real GDP. These findings are attributed to two sets of factors including the government's dominance of economic activity, the characteristics of the institutional environment surrounding the private sector, and some functional and structural characteristics of the financial system that impeded its development.

The paper is structured along the following lines. Sec- tion (2) briefly reviews the recent literature on financial development and growth. It sets out the theory and empirics on the relationship between financial development and economic growth. Section (3) briefly reviews the Saudi's banking sector with emphasis on the trend over the study period of the three measures of financial intermediation considered in the analysis. The sectoral allocation of bank credit will also be discussed. Section (4) discusses the research methodology, including model specification, methods of analysis, as well as the data and its trends. Section (5) discusses the empirical results, while Section (6) concludes the paper with some final remarks.

\section{Financial Development and Growth: A Brief Review of the Literature}

At the theoretical level, financial intermediaries play several roles in fostering economic growth. In a nutshell, these roles include: 1) Mobilization of investment funds and their efficient allocation their highest-return activeties; 2) Provision of liquidity insurance by reducing risk; 3) Allowance of an efficient risk pooling among different investment projects; 4) amelioration of information asymmetries to achieve efficiency in screening and monitoring investment projects ${ }^{3}$.

At the empirical level, disagreements emerged among economists on the role of financial systems in economic growth. Robinson (1952), for example, argued that the financial system did not spur economic growth, but simply responded to developments in the real sector. More recent evidence, however, supported the view that financial intermediation is essential for growth.

Following the pioneering work of [4], several authors examined the empirical relationship between financial intermediation and economic growth using time series and panel data at the country or regional levels. Using data from 35 countries during 1860-1963, [4] observed parallelism between economic growth and financial development. References [5,6] reached similar conclusions for a number of countries. Similarly, [7,8] have provided evidence in support of [4-6] that financial development enhances economic growth through higher investment levels and improvement in investment productivity or efficiency in capital allocation. From a large cross-country sample, [9] observed that financial deepening (measured by bank credit to the private sector as a ratio to GDP) enhances growth through both channels, particularly the efficiency effect.

From a sample of 21 developing countries during 19711980, [10] observed a significant positive relationship between real GDP growth rate and the interest rate dummy variable measuring financial repression. However, [9] argued that real interest rates are far from being good indi-

${ }^{3}$ See for example [12,13]. Reference [1] presents an excellent review of the literature on the growth promoting effects of financial intermediation. 
cators of financial development or repression. Reference [11] emphasized the role of government policy in the relationship between financial intermediation and growth. They developed a model in which financial repression is used to broaden the inflation tax base to finance government expenditure. In an optimal taxation framework, where inflation and income taxes are used as tax instruments, it is shown that high income tax evasion induces policymakers to repress the financial system through a high inflation rate to generate higher revenues from the inflation tax. Financial repression hampers growth because it reduces savings and capital productivity.

The role of risk-pooling and monitoring functions of financial intermediaries on economic growth was highlighted by [12]. Banks ensure higher expected rates of return and promote growth through allocating savings for diversified investment and by monitoring the behavior of borrowing firms. A similar impact of portfolio diversifycation via the stock market was also considered by [13]. In both models economic growth and financial development reinforce each other. The role of banks in liquidity management was further emphasized by [14]. Financial intermediaries reduce low return investment due to premature liquidation and redirect funds into longer-term and high-yield projects, leading to faster growth.

Reference [15] analyzed the effect of financial market development on saving rates and of borrowing constraints on economic growth, thus shifting the focus from the effects of financial markets on the production side of the economy to the effects on household behavior. They concluded that inability to borrow against future income induces individuals to increase savings. Thus, on the side of consumer credit, financial deepening is unlikely to increase savings. This result is consistent with casual observation in Latin America, where episodes of financial liberalization have not increased saving rates.

Further support for the "finance causes growth" hypothesis was provided by [16] who used time-series regression analysis for 71 developing countries during different periods that span the 1960s and 1980s. It is observed that financial intermediation promoted economic growth in roughly eighty five percent of the countries and that the growth-promoting patterns of financial intermediation were practically invariant across various countries and regions.

The joint endogeneity of financial development was addressed by [17] through the use of instrumental variables in the growth regressions. Countries' legal origin was used as the "external" instrument for financial depth in the crosssectional regressions, while lagged observations of all explanatory variables were used as "internal" instruments in the pooled regressions. The data panels consisted of about 74 countries and covered the period 1960-1995, with no overlapping five-year averages for countries. The five-year averages were used to smooth out transitory or business-cycle fluctuations. The authors found robust evi- dence that financial development and depth lead to better growth performance.

Employing Geweke decomposition test on panel data for 109 countries during 1960-1994, [18] observed that the longer the sampling interval, the larger the effect of financial development on economic growth. Further, despite the two-way Granger causality between financial development and economic growth, the former generally leads to the latter. Finally, financial deepening propels economic growth more strongly through rapid capital accumulation and to a lesser extent through productivity growth, while the strength of the causal relationship is observed more for developing than for industrial countries.

From a sample of ten developing countries during 19702000, [19] observed long-run causality from financial development (measured by bank credit, stock market capitalization, and outstanding debt securities as ratios to GDP) to economic growth, while no evidence is observed for short-run causality between financial deepening and output. The authors argued that policies to improve financial markets have a significant, though delayed effect, on growth.

Using panel data for the Spanish regions during 19862001, [20] examined the impact of developments and innovations in various regional banking sectors on regional growth. A positive and significant correlation is observed between bank financial deepening and regional growth. This evidence is more emphasized by the sources of financial intermediaries' development: product and service delivery innovations contributed positively to gross savings, investment and GDP growth.

The most skeptical view of the importance of financial development for growth was reported in [21,22]. While [21] applied variance decomposition analysis on quarterly time-series data during 1985-1998 for eleven countries, [22] used panel analysis based on the large panel data set provided by [17]. These studies reached different conclusions. Reference [21] found little evidence that financial development leads economic growth in the eleven countries. Also, no substantial differences were observed between eight Western countries with more developed financial systems and the three Asian countries with less developed financial systems. The author concluded: "To the limited extent that one does find some support for the hypothesis that financial development leads economic growth, it seems clear that financial development is no more than a contributing factor and, almost certainly, not the most important factor. It is clear that whatever causality may exist, it is not uniform in direction or strength, and highlights the inappropriateness of cross-sectional analysis in this regard". However, [22] found no evidence of a positive unidirectional causal link from financial development to economic growth. On the contrary, there is substantial evidence that economic growth preceded subsequent financial development. This result does not imply that the role of financial development is not important, 
but that the bottom line is that a more balanced approach to studying the relationship between finance and growth needs to be adopted. They were motivated by the casual observation that superstar East Asian countries with the world's highest growth rates for the last four decades, such as Japan, South Korea, and China, are not more financially developed than their competitors, especially South Korea whose financial institutions did not operate under market forces until very recently.

With the exception of few cases, the evidence on the finance-growth linkages in Africa suggested that financial development has a positive effect on economic growth. For Sub-Saharan African countries, [23] observed that financial intermediation, measured either by $\mathrm{M}_{2}$ as a ratio to GDP or by the growth rate of per capita real money balances, spurs growth.

At the level of individual Arab countries, [24] observed a moderate positive relationship between financial deepening and economic growth for Egypt during the period 1960-2001. The results strongly support the view that financial development Granger causes economic growth either through increasing investment efficiency or through mobilizing resources for investment. In contrast, [25] observed a weak relationship between financial development and economic growth for Sudan, mainly as a result of inefficiency in resource allocation by banks and the absence of an appropriate investment climate to foster significant private investment and promote growth in the long run.

\section{Salient Features of the Saudi's Banking Sector}

Here we briefly outline the salient features of the Saudi's banking sector, including the trends in variables that may capture the impact of financial development on growth, namely bank credit to the private sector, bank liquidity, and money supply. Non-financial variables that impact on growth are discussed in Section (4).

Banks dominate the Saudi's financial sector. Although it is the largest economy among the GCC countries, there are only 17 banks $^{4}$ (compared to 32 banks in Bahrain and 33 banks in UAE). According to [26], the Saudi's banking sector is also relatively small in terms of assets, with a total ranging between 60 percent and 70 percent of GDP during 2002-2008, and to 68 percent at end of 2008, compared to 258 percent for Bahrain, 142 percent for UAE, and 94 percent for Qatar. Assets of government and quasi government banks represent 35 percent of total bank as-

\footnotetext{
${ }^{4}$ There are 12 domestic banks and 5 foreign banks. Domestic banks include The National Commercial Bank, Samba Financial Group, Riyadh Bank, Banque Saudi Fransi, Saudi British Bank, Arab National Bank, Saudi Hollandi Bank, Saudi Investment Bank, Bank AlJazira, and Al Rajhi Bank, Bank AlBilad, Alinma Bank which adopt Islamic principles; foreign banks include Emirates Bank, National Bank of Kuwait, Deutsche Bank BNP Paribas, Bank Muscat.
}

sets, compared to 52 percent for UAE and 13 percent for Kuwait, while those of private banks represent 52 percent of total assets, compared to 87 percent for Kuwait and 75 percent for Qatar. The remaining 13 percent represents the share of joint venture banks (mostly by non-GCC investors) in the total assets of the sector, compared to 40 percent for Bahrain and 30 percent for Oman.

Saudi's banks are relatively concentrated in the hands of few domestic players, reflecting entry barriers and licensing restrictions for foreign banks, including those of other GCC countries. The sector is also moderately concentrated in the three largest banks (National Commercial Bank, Samba Financial Group, and Al Rajhi Bank) which account for 45 percent of banks' total assets. Public ownership (including quasi government) is fairly extensive in four banks and reaches 80 percent in the largest bank, the National Commercial Bank. There are five sizable specialized credit institutions with asset size close to half that of the banking sector. These provide interest free loans for public policy purposes. There are also three autonomous government institutions (the Pension Fund, the General Organization for Social Insurance, and the Saudi Fund for Development) that dominate the primary market for government securities. The remaining non-bank financial institutions account for a marginal share in total assets of the financial system [26].

Bank credit to the private sector has witnessed significant growth, increasing in 2010 to more than 4.2 times its level in $1998^{5}$. Recent trends indicate that the ratio of private credit to GDP increased from 33.3 percent in 1998 to 48.0 percent in 2010 . Credit to the private sector has been spurred by the rise in world oil prices, which boosted government spending and GDP growth, as well as private sector income. The impact was translated into a concomitant increase in the demand and supply of bank credit. With regard to supply, bank deposits grew with private sector income, thereby boosting banks' lending capacity. As for demand, bank credit was reoriented from public to private sector. This should have spurred private sector activities and investment. However, as in some GCC countries, high rates of credit growth observed more recently in Saudi Arabia may have increased the systems' vulnerability to a downturn in economic activity ${ }^{6}$. Further, the dominant role of the public sector has undermined the role of the private sector in the in the economy. Thus, little bank credit has been allotted to the productive sectors in more recent times [27]. The share of agriculture in bank credit has not exceeded 1.5 percent during 1998-2010, while the share of the mining sector ranged between 0.26 and 1.08 percent. Although the industrial sector is expected to play a pivotal role in the diversification process, it

\footnotetext{
${ }^{5}$ Bank credit in 2010 was equivalent to more than 485 times its level in 1968.

${ }^{6}$ This is in line with the international experience, when credit growth during an economic upturn almost invariably leads to high credit defaults following a slowdown in economic activity.
} 
received a maximum share of 14.3 percent in 1999 , which declined to 7.6 in 2006 before recovering to reach 11.6 percent in 2010. Indeed, bank credit has been reoriented towards the non-productive sectors, particularly the construction and trade sectors, although their shares have declined over time to give way for the "Other" sectors, whose share has increased from 24.7 percent in 1998 to 36.7 percent in 2010. The decline in the share of construction is most noticeable, from 11.65 percent in 1999 percent to only 7.3 percent in 2010 . These resources were shifted to the stock market, which helped in insulating the sector from the negative externalities of the contagion effects of financial crises that erupted in market economies.

At yet another level, total bank credit to the household sector also witnessed significant growth in more recent times $^{7}$, at an annual average rate of 146.3 percent during the period. While these loans represented 12.5 percent of total bank credit in 1998, they increased dramatically to absorb more than 63.0 percent of total bank credit in 2007 [27]. This reflects the limited and narrow real investment opportunities available for the Saud's banking sector. As a result, banks opted for providing consumption loans as well as loans for speculators in the stock and real estate markets, leading to high stock and real estate prices.

Although financial intermediation could have strong positive externalities on growth through the provision of liquidity and information for investors, some functional and structural features of the financial system have impeded its development. In particular, the Saudi's banking system is characterized by weak competition ${ }^{8}$ and lack of experienced personnel with sufficient expertise in credit analysis. Banks also suffer from the lack of financial innovation, particularly with regard to Islamic financial products. In a recent study, [28] observed that banks in Saudi Arabia are the least efficient among GCC countries, followed by those in UAE and Qatar, while banks in Oman are the most efficient followed by those in Bahrain and to a lesser extent by banks in Kuwait.

Finally, broad money supply increased at an average annual phenomenal rate of 877.6 percent during the period. The most noticeable increase in money supply occurred during 1974-1980, when it jumped from SR 8.7 billion in 1973 to SR 14.1 billion in 1974 and further to SR 94.4 billion in 1980. This coincided with the rise in world oil prices. A similar trend is observed for total liquidity as a ratio to $G D P$.

\section{Research Methodology}

\subsection{Model Specification}

Earlier studies on economic growth and financial inter-

\footnotetext{
${ }^{7}$ These loans take different forms, including consumption loans, credit card loans, personal loans, and real estate loans.

${ }^{8}$ There are only 17 banks in Saudi Arabia, compared to 33 in Bahrain, for example.
}

mediation (e.g. [7,8,29-31]) used the growth rate of real $G D P$ as a measure of economic growth. This study uses the natural logarithm of real GDP at 1999 prices as a measure of economic growth ${ }^{9}$.

Two sets of explanatory variables that impact economic growth are considered in the analysis. The first includes variables that capture the impact of financial development, while the second captures the impact of factors other than financial development. What constitutes an appropriate measure of financial development seems to be controversial. This is further complicated by the diversity of financial services offered by the financial system. The ratio of liquid liabilities to GDP is one such indicator. It is a standard measure of financial depth and the size of the financial sector. Several measures representing the liquid liabilities of the financial system, such as money supply to output ratio have been widely used in econometric models (e.g. $[4,7,8,32])$. These indices, however, are more likely measures of the extent to which transactions are monetized and may not reflect the ability of the financial system to channel funds from depositors to investment opportunities. As an alternative measure, bank credit to the private sector could be a superior measure of financial development since it goes beyond the size effect of financial intermediation; it provides more information on the level of financial services and the growth promoting activities of financial intermediaries. In a sense, it measures the quantity and quality of investment ${ }^{10}$ (see $[9,17]$ for a similar argument).

In light of the above, and to ensure robustness, this study considers three indicators of financial development. The first indicator is defined by the size of the financial intermediary sector. Following [33], this indicator (LIQ) is measured by the sector's liquid liabilities (currency plus demand and interest-bearing liabilities of banks) as a ratio to nominal GDP. The second indicator combines both the size and depth of financial intermediary activity of the sector. Broad money supply $M_{3}$ as a percentage of GDP $(M G D P)$ has become a standard measure of financial depth as well as an indicator of the overall size of financial intermediation activity. An increase in $M_{3}$ may be interpreted as an improvement of financial deepening in the economy. The third indicator of financial intermediation $(C P S)$ is defined by private credit extended to the private sector by commercial banks as a ratio to nominal GDP. In line with [9], this ratio emphasizes the important role the financial sector plays, especially commercial banks, in financing the private economy. CPS is an exclusive measure of the intermediary role of commercial banks since it excludes credit issued to the private sector from credit issued to governments and its agencies and

\footnotetext{
${ }^{9}$ Nonoil real GDP was used in the analysis, but most of the results were economically meaningless.

${ }^{10}$ It measures the quality of investment by indicating whether credit is allocated to the most productive activities.
} 
enterprises, as well as credit issued by the Central Bank [17]. The underlying assumption is that bank credit extended to the private sector impacts on investment and productivity to a much larger extent than does the credit provided to the public sector. The reason is that loans to the private sector are provided under more stringent conditions, including rigor in the evaluation of project viability and project progress, leading eventually to improved quality of investment $^{11}([1,32])$. This variable represents a more adequate indicator of financial development since it captures the role of banks in financial intermediation and measures the ability of the banking system to channel savings to investors, thereby leading to growth [32].

In order to control for the possible effects of other growth determinants, the regressions also involve variables other than those related to financial development. These include gross investment as percent of GDP (INV), size of government also as percent of $G D P(G)$, human capital $(H)$, and openness to trade (OPEN). The empirical literature indicates that these variables are robust determinants of growth. The share of investment in GDP is one of the few economic variables that have robust effect on growth [34]. Government expenditure could reduce economic growth because of the crowding out effect on private investment and the inflationary pressure it may create. However, there could be positive effects related to infrastructure investment. The size of the government is measured by the percentage share of public expenditure in GDP. Human capital is also an important variable that is commonly added to these types of models (Levine, 1997). To control for human capital we use the number of those who completed secondary schooling. Together with public expenditure, the inflation rate enters the regression to control for macroeconomic stability $[17,35,36]$. High inflation creates distortions in economic activity and reduces investment in productive enterprises, thus reducing economic growth. However, with relatively stable prices in Saudi Arabia, this variable is not included in the analysis. Finally, the effect of international trade on growth is captured by the degree of openness, measured by the share of the sum of imports and exports in nominal GDP [17]. Theoretically, trade can have both positive and negative effects on growth, with the net effect being determined empirically.

Based on the above, and following the literature (e.g. King and Levine, 1993a, 1993b; Allen and Ndikumana, 1998), we estimate three versions of the model of the impact of financial development on growth in Saudi Arabia. The three versions are different in that the dependent variable (the natural logarithm of real GDP) will be regressed on each of the three indicators of financial development, namely the size of the financial intermediary

\footnotetext{
${ }^{11}$ However, this argument might not hold when private loans are influenced by political and other institutional factors.
}

sector (LIQ), financial depth (MGDP), and bank credit to the private sector (CPS). The rest of explanatory variables included in the regressions are the same. Thus, after taking the natural logarithm of the variables, the three estimable versions of the model are given below:

$$
\begin{aligned}
\ln R G D P_{t}= & \alpha_{0}+\alpha_{1} t+\alpha_{2} \ln I N V+\alpha_{3} \ln G_{t}+\alpha_{4} \ln H_{t} \\
& +\alpha_{5} \ln O P E N_{t}+\alpha_{6} \ln F I N D_{t}+u_{1 t}
\end{aligned}
$$

where FIND stands for the financial development variable, which is either LIQ, or MGDP, or CPS; $\ln I N V$ is the $\log$ of current investment/GDP ratio; $\ln G$ is the $\log$ of government spending/GDP ratio; $\ln H_{\mathrm{t}}$ is the $\log$ of human development; $\ln O P E N$ is the log of trade openness; $t$ is time trend, and $u$ is a white noise error term. Each of the equations in (1) represents only the long-run equilibrium relationship and may form a cointegration set provided that all variables included in each equation are integrated of order one, i.e. I(1).

\subsection{Analytical Methods}

Annual time series data obtained from the Annual Reports of Saudi Arabian Monetary Authority (SAMA) for the period $1968-2010$ is used in the analysis. To examine the empirical long-run relationships and dynamic interactions among the variables, the model is estimated using the autoregressive distributed lag $(A R D L)$ bounds testing approach to cointegration, as developed by [37-39]. The $A R D L$ procedure is adopted for three reasons. First, it is simple compared to other conventional multivariate cointegration techniques ${ }^{12}$. In particular, while the conventional cointegration method estimates the long-run relationship in the context of a system of equations, the ARDL procedure allows the estimation of a single cointegration relationship by OLS method once the lag order of the model is identified (Pesaran and Shin, 1995). Second, unlike other techniques such as the Johansen approach, the ARDL method is applicable irrespective of whether the regressors in the model are purely $I(0)$, or purely $I(1)$ or a mixture of both, meaning that it does not require pre-testing the model variables for unit roots. However, since the $A R D L$ procedure collapses in the presence of $I(2)$ series, pre-testing the model variables for unit roots becomes necessary to determine their order of integration and avoid spurious results. Third, the ARDL procedure performs better in small or finite samples (as in the present study) in the sense that it gives relatively more robust (efficient) results than other cointegration techniques. Since the validity of cointegration techniques such as that of Johansen requires large data samples, this study adopts the bounds testing approach on a sample size of 42 annual observations to examine the cointegrating relationship between economic

\footnotetext{
${ }^{12}$ Examples of these include the two-step residual based test due to [40], and the maximum-likelihood based tests due to $[41,42]$.
} 
growth and financial development for Saudi Arabia.

The first step is to run the $A D F$ unit root test to examine stationarity of the series of variables involved in the three versions of the model in Equations (1). The null hypothesis is that the variable in question has a unit root (i.e. it is non-stationary), which is tested against the alternative hypothesis that the variable has no unit root (i.e. it is stationary). Along the lines of [37], if all variables involved are stationary, the next step is to apply the bounds testing approach to examine cointegration between the variables. According to [38], the bounds testing approach to cointegration involves three steps. The first is to write each of the long-run equilibrium equations in (1) in the form of an autoregressive distributed lag $(A R D L)$ model. Assuming maximum lag lengths of $q$ and $k$ for the dependent and explanatory variables, respectively, the general (unrestricted) error correction models (ECMs) underlying the three $A R D L$ models in Equation (1) are given by:

$$
\begin{aligned}
\Delta \ln R G D P_{t}= & \alpha+\beta t+\lambda_{1} \ln R G D P_{t-1}+\lambda_{2} \ln I N V_{t-1} \\
& +\lambda_{3} \ln G_{t-1}+\lambda_{4} \ln H_{t-1}+\lambda_{5} \ln \text { OPEN }_{t-1} \\
& +\lambda_{6} \ln F I N D_{t-1}+\sum_{i=1}^{q} \xi_{i} \Delta \ln R G D P_{t-i} \\
& +\sum_{i=1}^{k} \theta_{i} \Delta \ln I N V_{t-i}+\sum_{i=1}^{k} \phi_{i} \Delta \ln G_{t-i} \\
& +\sum_{i=1}^{k} \psi_{i} \Delta \ln H_{t-i}+\sum_{i=1}^{k} \delta_{i} \Delta \ln O P E N_{t-i} \\
& +\sum_{i=1}^{k} \eta_{i} \Delta \ln F_{N} D_{t-i}+u_{1 t}
\end{aligned}
$$

where FIND is as defined above; the parameters $\lambda_{1}, \lambda_{2}$, $\lambda_{3}, \lambda_{4}, \lambda_{5}$, and $\lambda_{6}$ are the long-run parameters (elasticities), while $\theta_{i}, \phi_{i}, \psi_{i}, \delta_{i}, \eta_{i}$ are the short-run dynamic coefficients of the underlying $A R D L$ model, and $u_{i t}$ are white noise errors. In the second step of the bounds testing approach, we examine cointegration (i.e. the existence of a long-run relationship between the system variables). This is accomplished by applying OLS methods to estimate each of the three versions of the (unrestricted) ECMs given in Equation (2). Since the coefficients $\lambda^{\prime} s$ of the lagged variables represent the long-run parameters of the underlying $A R D L$ model, the existence of a long-run relationship among the variables is examined by conducting an $F$-test for the joint significance of these coefficients. Thus, for each of the three versions in Equation (2), the null hypothesis of no cointegration (no long run relationship among the system variables) is written as

$H_{0}: \lambda_{1}=\lambda_{2}=\lambda_{3}=\lambda_{4}=\lambda_{5}=\lambda_{6}$, which is tested against the alternative hypothesis $H_{1}: \lambda_{1} \neq \lambda_{2} \neq \lambda_{3} \neq \lambda_{4} \neq \lambda_{5} \neq \lambda_{6}$.

As usual, the $F$-test involves applying OLS to estimate each of the equations in (2). Then impose the restrictions given by $H_{0}$ and re-estimate the equations with the first difference terms only. From the two regressions calculate the $F$-statistic and test for the joint significance of the parameters of the lagged level variables. According to Pesaran, et al. (2001), the statistic underlying this procedure is the familiar Wald or F-statistic in a generalized Dickey-Fuller type regression, which is used to test the significance of the lagged variables in the unrestricted long-run equilibrium ECM. However, the distribution of this $F$-statistic is non-standard in the sense that it depends on: a) the number of regressors $(m)$; b) whether the variables in the system are $I(0)$ or $I(1)$; and c) whether the model contains an intercept and/or a trend term. Nonetheless, $[37,43]$ generated two sets of asymptotic critical values of $F$-statistics that cater for these aspects. In general, these two sets provide a test for cointegration when the regressors are $I(d)$, where $0 \leq d \leq 1$. This means that, for each application, the two sets provide the bands covering all possible classifications of the regressors that are $I(0)$ or $I(1)$, or mutually integrated. In particular, the set of lower critical values bounds corresponds to the case where all the variables in the $A R D L$ model are 1(0), while the set of upper critical values bounds assumes that all the variables are 1(1).

If the computed $F$-statistic exceeds the corresponding upper critical bound value for a given significance level, the null hypothesis (of no cointegration) is rejected. This means that there is evidence of a non-spurious long-run level relationship between the regressors and the dependent variable, regardless of the order of integration of the variables. If the computed $F$-statistic lies below the corresponding lower critical bound value, the null hypothesis (that there is no long-run level relationship between the regressors and the dependent variable) is accepted; and if the computed $F$-statistic lies within the lower and upper critical bound values, the result is inconclusive, meaning that no inference can be made without knowledge of the order of integration of the underlying regressors.

The ARDL model requires prior knowledge (selection) of the lag orders of variables, which is also sufficient to correct for autocorrelated residuals and the problem of endogenous regressors simultaneously [38]. Thus, if there is evidence for the existence of cointegration (long-run relationship) between variables, the third step involves selecting the appropriate lag orders of the dependent variable and regressors involved to obtain what is known as the conditional (restricted) $A R D L$ model. This is normally accomplished by applying OLS methods to estimate the general $A R D L$ model of the form:

$$
\begin{aligned}
& \ln R G D P_{t} \\
= & \alpha+\beta t+\sum_{i=1}^{q} \lambda_{1 i} \ln R G D P_{t-i}+\sum_{i=0}^{k_{1}} \lambda_{2 i} \ln I N V_{t-i} \\
& +\sum_{i=0}^{k_{2}} \lambda_{3 i} \ln G_{t-i}+\sum_{i=0}^{k_{3}} \lambda_{4 i} \ln H_{t-i}+\sum_{i=0}^{k_{4}} \lambda_{5 i} \ln O P E N_{t-i} \\
& +\sum_{i=0}^{k_{5}} \lambda_{6 i} \ln \text { FIND }_{t-i}+u_{t}
\end{aligned}
$$


Following [38], because of the small size of annual data a maximum lag length of two is used, so that $\left(q=2, k_{i}=\right.$ 2 ) in Equation (3) $)^{13}$. The next step involves applying $O L S$ to the conditional (restricted) ARDL long-run models in Equation (3) to obtain estimates of the long-run parameters $\lambda_{1}, \lambda_{2}, \lambda_{3}, \lambda_{4}, \lambda_{5}$, and $\lambda_{6}$. The estimated equation is also used to obtain an estimate of the error correction term $\left(E C_{t-1}\right)$, which is obtained from Equation (3) as:

$$
\begin{aligned}
E C_{t-1}= & \ln R G D P_{t}-\alpha-\beta t-\sum_{i=1}^{q} \lambda_{1 i} \ln R G D P_{t-i} \\
& -\sum_{i=0}^{k_{1}} \lambda_{2 i} \ln I N V_{t-i}-\sum_{i=0}^{k_{2}} \lambda_{3 i} \ln G_{t-i} \\
& -\sum_{i=0}^{k_{3}} \lambda_{3 i} \ln H_{t-i}-\sum_{i=0}^{k_{4}} \lambda_{4 i} \ln O P E N_{t-i} \\
& -\sum_{i=0}^{k_{5}} \lambda_{5 i} \ln \text { FIND }_{t-i}
\end{aligned}
$$

Once the conditional ARDL models in Equation (3) are estimated, we apply statistical diagnostic tests to examine model specification and functional forms. These tests include the well known regression specification error test (RESET) to examine the functional form, Breusch-Godfrey autocorrelation test, White's general heteroscedasticity test, and Jarque-Bera normality test. Finally, stability of the estimated coefficients over the sample period will also be examined by adopting the recursive residual test for structural stability. The Cumulative Sum of Recursive Residuals (CUSUM) and the Cumulative Sum of Square of Recursive Residuals (CUSUMQ) obtained from a recursive estimation of the models will be plotted against the time horizon of the sample. These are compared with the bound critical values at specified significance level. If the plot of the CUSUM and CUSUMSQ remains within the boundaries of the 5 percent critical bound the null hypothesis that all coefficients are stable cannot be rejected.

After the long-run parameters and the error correction term are estimated, the final step involves estimating the short-run dynamic parameters by applying OLS to the error correction representation of the conditional $A R D L$ model in Equation (3). The ECM model is given by:

$$
\begin{aligned}
& \Delta \ln R G D P_{t} \\
= & \alpha+\beta t+\sum_{i=1}^{q} \xi_{i} \Delta \ln R G D P_{t-i}+\sum_{i=1}^{k_{1}} \theta_{i} \Delta \ln I N V_{t-i} \\
& +\sum_{i=1}^{k_{2}} \phi_{i} \Delta \ln G_{t-i}+\sum_{i=1}^{k_{3}} \psi_{i} \Delta \ln H_{t-1} \\
& +\sum_{i=1}^{k_{4}} \delta_{i} \Delta \ln O P E N_{t-i}+\sum_{i=1}^{k_{5}} \eta_{i} \Delta \ln \text { FIND }_{t-1} \\
& +\rho E C_{t-1}+u_{1 t}
\end{aligned}
$$

${ }^{13}$ There may or may not be a trend and constant terms in the selected ARDL model. where $E C_{t-1}$ is the error correction term in (4) obtained from Equation (3). The parameters $\xi_{i}, \theta_{i}, \phi_{i}, \psi_{i}, \delta_{i}, \eta_{i}$ in Equation (5) are the short-run dynamic coefficients which measure the model's convergence to equilibrium, while the coefficient of the error correction term $\rho$ is the adjustment parameter, which gives the proportion of the deviations (errors) of the dependent variable from its long-run equilibrium value that has been adjusted (corrected). The coefficient must be negative and statistically significant. The negative sign of the coefficient means that the dependent variable adjusts back to its equilibrium value (or the dynamic model converges to equilibrium) following a disturbance; the magnitude of the coefficient measures the speed of adjustment.

Before concluding this section, we briefly examine the trends in the non-financial variables of the model. The data obtained from [27] shows that the Saudi's economy witnessed an impressive growth performance of real GDP over the last four decades (1968-2010), growing at an average annual rate of 14.4 percent. Being a predominantly oilproducing country, many of the macroeconomic variables in Saudi Arabia mirror the developments in the energy sector, which is very much influenced by developments in the world oil market. The economy registered an average annual growth rate of 15.3 percent during 1968-1972, mainly because of the rise in oil production by an annual average rate of 24.4 during that period. While oil production increased at a moderate rate of 3.2 percent per annum during 1973-1981, real output increased at 12.3 percent per annum, mainly because of the significant rise in oil prices. Following the peak of 1982, the fall in oil prices and the corresponding drop in crude oil production, real output declined sharply at an annual average rate of 2.4 percent during 1982-1987. The economy recovered in 1988, due primarily to the subsequent upturn of the world oil market, and has expanded since then at a rate of approximately 4.2 percent per annum ${ }^{14}$.

As noted earlier, the Saudi's government has played a major role in the economy. This role is further enhanced by the increase in Government's income due to high oil prices, thereby boosting investment in the oil and non-oil sectors. Thus, government expenditure and investment exhibited patterns of evolution similar to that of GDP. Government consumption expenditure increased dramatically in 1973 to more than 49 times its level in 1968 and in 1981 to more than 15 times its level in 1973. It then exhibited a downward trend until 1999 before rising again in 2010. The share of government expenditure in GDP rose steadily from 32.9 percent in 1968 to reach an all time high level of 78.6 percent by 1976 . Since then, this share continued to fall to reach 33.7 percent in 2009 , due

\footnotetext{
${ }^{14}$ The growth impact of the stabilization and structural adjustment program, which commenced in early 1990s and included economic privatization and liberalization of the real economy, is yet to be assessed.
} 
primarily to the rise in GDP following the windfall gains from oil exports. Despite this and the measures taken to pave the way for private sector participation ${ }^{15}$, the Government remained involved in a wide range of activities ${ }^{16}$, while it has continued to invest heavily in the energy sector, particularly in the hydrocarbons and natural gas Industries. Thus, it is believed that government expenditure have contributed significantly to growth. Likewise, gross domestic investment has exhibited an upward trend. Along the lines of conventional growth theory, gross capital formation should have a positive impact on growth.

The Government has also invested heavily on social development services, including education, training, health, nutrition, social security and welfare, housing and other social services. Expenditure on these services has been rising over time, expanding from 12.2 percent of total expenditure in 1985 to 20.4 percent of total expenditure in 2007. However, expenditure on economic services and infrastructure declined from 9.4 percent of total expenditure in 1985 to 2.3 percent of total expenditure in 2007. Nonetheless, this is still a major contribution to developing the economic infrastructure in view of the considerable effort that has already been made in this respect during the 1980s and the early 1990s, when it figured out as one of the major expenditure categories.

The government has also adopted an ambitious strategy of investment in education and training, particularly since the early 1980s, with a view to improving the quality of human capital. In 1985 current expenditure on education amounted to 16.7 percent of total expenditure, and increased over the years to reach 25.2 percent of total expenditure in 2007. The number of those who completed secondary school education level has exhibited a strong upward trend, increasing in 2010 to nearly 109.4 times their level in 1968. The data on educational attainment also indicate that those who completed higher school education level increased from 0.54 percent in 1974 to 8.01 percent in 2010. In line with the United Nations Human Development goals, investment on human capital has also been accompanied by policies to ensure that each member of the population has access to basic education at the least. In line with endogenous growth theory, human capital should have a positive effect on national growth.

The index for trade openness suggests that the Saudi's economy is probably one of the most open and liberalized economies in the world, with the highest average index of 74.0 compared to 24.8 for the USA during 1992-2009 ${ }^{17}$. However, given the high dependency of the Saudi's economy on oil and the minimal restrictions on imports, the high index of trade openness is most likely a reflection of

\footnotetext{
$\overline{{ }^{15} \text { These measures include a program to restructure and privatize many }}$ of the state enterprises.

${ }^{16}$ These activities include petroleum and natural gas, chemicals, electricity and telecommunications.
}

the dominant oil exports which represented 85 percent of total exports in 2009. This makes the trade openness index highly sensitive to oil prices and production. The data suggests that since the late 1960s, the index has exhibited an upward trend to reach its peak of 85.6 in 1974 before trending down to 73.1 in 1975 and then recovering to reach another peak of 85.1 in 1980. The index declined once more and then exhibited some cyclical variations until it eventually reached an all time high level of 90.7 in 2008. Since these trends correspond more or less to similar trends in GDP, it is expected that trade openness would exert a positive impact on growth.

\section{The Empirical Results}

\subsection{Unit Root Test and Cointegration Analysis}

The first step involves examining stationarity of the series of the variables included in the three versions of the model as given in Equations (1). For this purpose, we run the $A D F$ unit root test for all variables. Although pretesting the variables for stationarity is not required in the $A R D L$ framework, it is still necessary to run the test to determine the order of integration of each variable and thus avoid spurious regressions. Results of the $A D F$ unit root test are reported in Table 1. Each variable is tested for stationarity using one or two lags. The results suggest that all variables are either $I(0)$ or $I(1)$, or both.

Since all variables involved are stationary, the next step is to apply the bounds testing approach to examine cointegration between them. The familiar Wald or F-statistic is used to test the significance of the lagged level variables under consideration in the unrestricted long-run equilibrium ECM [36]. The results are reported in Table 2. It is clear that the computed $F$-statistic for all equations exceeds the corresponding upper critical bound values at the $1 \%$ significance level. As such, we reject the null hypothesis (of no cointegration) and conclude that there is strong evidence of a non-spurious long-run level relationship between the regressors and the dependent variable in each model, regardless of the order of integration of variables.

\subsection{Estimation of the Long-Run Relationship}

After having established the existence of a long-run cointegration relationship, the different versions of Equation (3) were estimated using the $A R D L(0,0,0,0,1)$ specification. Table 3 reports the regressions of the long-run relationship. The adjusted coefficient of determination indicates a very high overall goodness of fit of all estimated versions of the long run models.

\footnotetext{
${ }^{17}$ The averages for the major economies during the same period amounted to 72.0 for Canada, 64.6 for Germany, 55.4 for Britain, 50.0 for France, 49.9 for China, 49.4 for Italy, 45.8 for Turkey, 40.6 for Australia, and 22.9 for Japan.
} 
Table 1. ADF unit root tests for stationarity of variables.

\begin{tabular}{|c|c|c|c|c|c|c|c|}
\hline \multirow{3}{*}{ Variable } & \multirow{3}{*}{ lag Length } & \multicolumn{5}{|c|}{ Calculated ADF Statistic } & \multirow{3}{*}{$\begin{array}{c}\text { Order of Integration } \\
\text { I(d) }\end{array}$} \\
\hline & & \multicolumn{2}{|c|}{ Log Level Variable $(\ln Z)$} & \multicolumn{3}{|c|}{ First Difference $(\Delta \ln Z)$} & \\
\hline & & With Intercept & $\begin{array}{l}\text { With Intercept } \\
\text { and Trend }\end{array}$ & $\begin{array}{l}\text { Without Intercept } \\
\text { and Trend }\end{array}$ & With Intercept & $\begin{array}{l}\text { With Intercept } \\
\text { and Trend }\end{array}$ & \\
\hline \multirow[t]{2}{*}{$\ln R G D P$} & 1 & $-3.3508 \mathrm{~b}$ & $-4.1159 b$ & -1.8952 & -2.1173 & -2.2509 & $I(0)$ \\
\hline & 2 & $-3.1031 b$ & $-5.0795 \mathrm{a}$ & $-2.2986 b$ & -2.4422 & -2.3756 & $I(0)$ \\
\hline \multirow{2}{*}{$\ln R I N V$} & 1 & $-2.6757 b$ & -2.7219 & -1.9325 & -2.2535 & -2.5368 & $I(0)$ \\
\hline & 2 & $-3.2302 b$ & $-3.7370 b$ & $-1.8976 \mathrm{c}$ & -2.1943 & -2.4729 & $I(0)$ \\
\hline \multirow[t]{2}{*}{$\ln G$} & 1 & -2.3409 & -2.9595 & $-5.8249 \mathrm{a}$ & $-5.7598 \mathrm{a}$ & $-5.7537 \mathrm{a}$ & $I(1)$ \\
\hline & 2 & -2.1452 & -3.1069 & $-4.3935 \mathrm{a}$ & $-4.3395 \mathrm{a}$ & $-4.3199 \mathrm{a}$ & $I(1)$ \\
\hline \multirow[t]{2}{*}{$\ln H$} & 1 & $-3.4267 \mathrm{~b}$ & -1.5166 & -1.2174 & $-3.4057 \mathrm{a}$ & $-5.7838 \mathrm{a}$ & $I(0)$ \\
\hline & 2 & $-4.6638 \mathrm{a}$ & -2.3285 & -1.2712 & -2.0507 & $-3.3773 \mathrm{c}$ & $I(0)$ \\
\hline \multirow[t]{2}{*}{$\operatorname{lnOPEN}$} & 1 & -1.7182 & -1.6624 & $-4.2350 \mathrm{a}$ & $-4.2251 \mathrm{a}$ & $-4.1852 \mathrm{a}$ & $I(1)$ \\
\hline & 2 & -1.6597 & -1.5976 & $-2.9367 \mathrm{a}$ & $-2.9009 \mathrm{c}$ & -2.9321 & $I(1)$ \\
\hline \multirow[t]{2}{*}{$\ln L I Q$} & 1 & -1.2778 & -2.8921 & $-5.0432 \mathrm{a}$ & $-5.2117 \mathrm{a}$ & $-5.1362 \mathrm{a}$ & $I(1)$ \\
\hline & 2 & -1.1914 & -2.6349 & $-4.1896 \mathrm{a}$ & $-4.4607 a$ & $-4.4002 \mathrm{a}$ & $I(1)$ \\
\hline \multirow[t]{2}{*}{$\ln M G D P$} & 1 & -1.0172 & -1.9276 & $-4.5837 \mathrm{a}$ & $-4.8978 \mathrm{a}$ & $-4.8425 \mathrm{a}$ & $I(1)$ \\
\hline & 2 & -1.0449 & -1.8493 & $-3.5845 a$ & $-3.9912 \mathrm{a}$ & $-3.9694 b$ & $I(1)$ \\
\hline \multirow[t]{2}{*}{$\ln C P S$} & 1 & -0.1191 & -2.8393 & $-4.4741 \mathrm{a}$ & $-4.8377 \mathrm{a}$ & $-4.8211 \mathrm{a}$ & $I(1)$ \\
\hline & 2 & -0.2571 & -2.6927 & $-3.0971 \mathrm{a}$ & $-3.6424 a$ & $-3.5060 \mathrm{c}$ & $I(1)$ \\
\hline
\end{tabular}

Source: Author's calculations. a, b, and c mean significant at $1 \%, 5 \%$, and $10 \%$, respectively.

Table 2. Cointegration test: Dependent variable $\triangle R G D P$.

\begin{tabular}{|c|c|c|c|c|c|c|}
\hline $\begin{array}{c}\text { Financial Variable } \\
\text { Included }\end{array}$ & $\begin{array}{c}\text { Observations } \\
(T)\end{array}$ & $\begin{array}{l}\text { Lagged First Differences } \\
(q \text { and } k)\end{array}$ & No. of Regressors & URSS & RRSS & F-Statistica \\
\hline \multirow{2}{*}{$L I Q$} & 41 & 1 & 12 & 0.068 & 0.114 & 19.489 \\
\hline & 40 & 2 & 18 & 0.041 & 0.100 & 31.612 \\
\hline \multirow{2}{*}{$M G D P$} & 41 & 1 & 12 & 0.075 & 0.115 & 15.174 \\
\hline & 40 & 2 & 18 & 0.051 & 0.102 & 22.130 \\
\hline \multirow{2}{*}{ CPS } & 41 & 1 & 12 & 0.078 & 0.114 & 13.219 \\
\hline & 40 & 2 & 18 & 0.059 & 0.097 & 14.095 \\
\hline
\end{tabular}

Source: Author's calculations. a. The lower and upper critical values bounds at the $1 \%$ significance level are 4.81 and 6.02 , respectively for first differences with one lag and 3.88 and 5.30, respectively for first differences with two lags.

Table 3. Estimation of long-run coefficients using the selected $A R D L(0,0,0,0,1)$ model for $\ln R G D P$.

\begin{tabular}{|c|c|c|c|c|c|c|}
\hline Model Version & Regressor & Coefficient & $t$-Ratio & Significance Level & $R^{2}$ & $\operatorname{Adj} R^{2}$ \\
\hline \multirow{6}{*}{1} & Constant & 8.7045 & 14.7524 & 0.0000 & \multirow{6}{*}{0.973} & \multirow{6}{*}{0.970} \\
\hline & LNRINV & 0.1079 & 5.3865 & 0.0000 & & \\
\hline & $L N G$ & 0.2704 & 3.6324 & 0.0009 & & \\
\hline & $L N H$ & 0.2250 & 5.8268 & 0.0000 & & \\
\hline & LNOPEN & 0.1118 & 1.3992 & 0.1706 & & \\
\hline & $L_{N L I Q_{-1}}$ & -0.1900 & -2.4408 & 0.0199 & & \\
\hline \multirow{6}{*}{2} & Constant & 8.7143 & 15.7958 & 0.0000 & \multirow{6}{*}{0.977} & \multirow{6}{*}{0.973} \\
\hline & LNRINV & 0.0994 & 5.2110 & 0.0000 & & \\
\hline & $L N G$ & 0.2746 & 4.0588 & 0.0003 & & \\
\hline & LNH & 0.2700 & 6.5397 & 0.0000 & & \\
\hline & LNOPEN & 0.0424 & 0.5249 & 0.6030 & & \\
\hline & $L N M G D P_{-1}$ & -0.2292 & -3.4428 & 0.0015 & & \\
\hline \multirow{6}{*}{3} & Constant & 8.1212 & 16.8551 & 0.0000 & \multirow{6}{*}{0.983} & \multirow{6}{*}{0.981} \\
\hline & LNRINV & 0.0804 & 4.7190 & 0.0000 & & \\
\hline & $L N G$ & 0.1439 & 2.5961 & 0.0137 & & \\
\hline & LNH & 0.3227 & 8.6523 & 0.0000 & & \\
\hline & LNOPEN & 0.1321 & 2.3133 & 0.0267 & & \\
\hline & LNCPS $_{-1}$ & -0.2291 & -5.4393 & 0.0000 & & \\
\hline
\end{tabular}

Source: Authors' calculations. 
The results suggest that in the long run capital investment, government expenditure, the stock of human capital and trade openness exert significant positive effects, while financial intermediation has a significant negative effect on real GDP. The estimated coefficient of capital investment (measured by real gross capital goods) is consistent with the central role assigned to physical capital accumulation in the growth literature. In all versions of the model, this coefficient indicates that, other things being equal, a $1 \%$ rise in physical capital accumulation leads to an increase in real GDP over time by $0.08-0.10$ percentage points. This low response of real GDP to investment may indicate the poor efficiency and low productivity of investment, and may be attributed to the fact that the Saudi's economy is based on capital and technology intensive oil and petrochemical sector, with limited employment and income generation benefits. The influence of oil prices on growth comes mainly through increasing the government's income, part of which is re-invested in the capital intensive oil sector.

Although government expenditure could reduce economic growth through the crowding out effect on private investment and the inflationary pressure it may create (Allen and Ndikumana, 2000), the evidence here indicates that it has increased the long-run level of GDP. This is consistent with the predictions of Keynesian macroeconomic theory. An increase in government expenditure by $1 \%$ leads to an increase in real GDP over time by 0.14 0.27 percentage points. This is far higher than the response of GDP to capital investment. Thus, to the extent that government spending is productive, fiscal policy has had a significant positive impact on growth. However, this does not necessarily mean that all categories of government spending increase output but that in the aggregate it does. For Saudi Arabia, this positive impact of government spending on growth may have come mainly through infrastructure investment

The positive effect of human capital on steady-state output is one of the fundamental predictions of endogenous growth models and is of no surprise here in view of the considerable efforts and the impressive education track record in Saudi Arabia during the last four decades. The coefficient on secondary level attainment implies that a rise in the number of pupils (15 years and above) who have successfully completed secondary schooling by 1 percent increases long-run real output by roughly 0.22 0.32 percentage points. Thus, it appears that the strategy of investment in education has been a successful one. This strategy has also been emphasized by a number of policies, including those to ensure access to at least basic-level education for the younger generation, and free education at the secondary school level. The figures on

\footnotetext{
${ }^{18}$ Some caution must be exercised in interpreting these results since the proportion of foreign workers in the labour force is quite significant.
}

school attainment indicate that the number of those whose highest level of education is at the secondary level has increased significantly over the sample period from 13.9 thousands in 1968 to 1520.3 thousands in 2010, representing nearly 110.0 times their level in 1968. Thus, the quality of human capital has improved over time, exerting a significant positive effect on growth ${ }^{18}$.

The coefficient of trade openness is highly significant in the third version of the model. Accordingly, an increase in trade openness by $1 \%$ leads to an increase in real GDP by 0.13 percentage points. However, it should be noted that the trade openness index might be capturing other developments and policies that encourage trade but unrelated to openness. On the one hand, where oil constitutes a considerable proportion of exports, the windfall gains emanating from increases in world oil prices have little or nothing to do with actual openness to trade in the traditional sense. On the other hand, the strong impact of trade openness on growth may be attributed partly to the fact that Saudi Arabia is classified as a sufficiently open economy in the sense of lower or no tariff and non-tariff barriers to trade. It is no doubt that the index of trade openness is capturing all such effects.

Finally, apart from adherence to Islamic Principles in financial dealings, the restrictions imposed on the Saudi's domestic financial system are judged to be minimal ${ }^{19}$. Despite this, the results overwhelmingly indicate that financial development has impacted negatively on the long-run level of real GDP. These findings could be attributed to two sets of factors that are by no means mutually exclusive. The first set relates to the structure of the Saudi's economy, particularly its high dependence on oil, together with the dominant role that the public sector plays in the economy. The measures that are currently being taken towards privatization and economic liberalization could provide real opportunities for the private sector to play a more positive role in economic activity, particularly in economic diversification. However, this role could still be hampered by the surrounding institutional environment, including lack of strong business and professional organizations, and the absence of an appropriate investment climate necessary for fostering significant private investment and long run growth. The second set of factors relates to the characteristic features of the Saudi's financial system, and has been discussed in Section (2). It includes the dominant role of the public sector in the economy and the allocation of bank credit to non-productive sectors, particularly loans extended to the household sector for consumption purposes. Other factors include the weak competition of the banking system and lack of lack of financial innovation, particularly with regard to Islamic financial products.

Table 4 reports the results of the diagnostic tests for

\footnotetext{
${ }^{19}$ These restrictions are intended mainly to fight money laundering and terrorism financing.
} 
the estimated long-run versions of the $A R D L$ model. All versions pass all diagnostic tests of normality, serial correlation, functional form, and heteroscedasticity. For each version, Jarque-Bera $\chi^{2}(2)$ test statistic has a very high $p$-value, suggesting normality of the residuals. Ramsey RESET F-statistic is highly significant, meaning that the model is correctly specified. White heteroscedasticity $\chi^{2}(2)$ test statistic with cross terms is also insignificant, suggesting that there is no heteroscedasticity in the models. However, Breusch-Godfrey $\chi^{2}(2)$ test statistic for serial correlation is highly insignificant for the version with CPS, indicating that the null of no serial correlation is accepted for that version only. We conclude that among the three estimated versions of the long-run model, the one involving CPS is the best specified and is also fre from serial correlation and heteroscedasticity problems.

The final step of the long-run analysis is to examine structural changes in real GDP. For this purpose, we have examined the stability of the model parameters using the cumulative sum of recursive residuals (CUSUM) and the cumulative sum of squares of recursive residuals (CUSU$M S Q$ ) test procedures. CUSUM and CUSUMSQ are plot- ted against the break points. Parameter stability is indicated when the CUSUM and CUSUMSQ plots against time remain within the 5 percent significance level over the sample period, while parameters and hence the variance are unstable if these plots move outside the 5 percent critical lines. The plots of the CUSUM and CUSUMSQ in Figures $\mathbf{1}$ and $\mathbf{2}$ are obtained from a recursive estimation of version 3 of the model (with bank credit to the private sector (CPS). These plots indicate stability in the coefficients and hence in the Saudi's real GDP during the sample period.

\subsection{Estimation of Short-Run Parameters}

The final step involves estimating the short-run dynamic coefficients. This is accomplished by using OLS method to estimate the ECM equations associated with the $A R D L$ long-run relationships. Table 5 reports the results of the error correction representation of the estimated versions of the ARDL model. The signs of the short-run dynamic coefficients are the same as those of the long-run coefficients for the underlying $A R D L$ equation. However, government expenditure, human capital, and openness to trade

Table 4. Diagnostic tests of the estimated long-run ARDL models for InRGDP (P-Values).

\begin{tabular}{|c|c|c|c|c|c|c|}
\hline \multirow[b]{2}{*}{ Version } & \multirow[b]{2}{*}{ Normality (Jarque-Bera) } & \multicolumn{2}{|c|}{ Functional Form } & \multicolumn{2}{|c|}{ Autocorrelation } & \multirow{2}{*}{$\begin{array}{l}\text { White } \\
\text { Heteroscedasticity }\end{array}$} \\
\hline & & $A I C$ & $\begin{array}{l}\text { Ramsey } \\
\text { RESET } \\
\end{array}$ & $D W$ & Breusch-Godfrey & \\
\hline 1 & $\begin{array}{c}0.5033 \\
(0.7775)\end{array}$ & -2.1974 & $\begin{array}{l}21.258 \\
(0.000)\end{array}$ & 0.960 & $\begin{array}{l}11.7351 \\
(0.0194)\end{array}$ & $\begin{array}{l}27.1266 \\
(0.1317)\end{array}$ \\
\hline 2 & $\begin{array}{c}0.1845 \\
(0.9119)\end{array}$ & -2.3319 & $\begin{array}{l}22.097 \\
(0.000)\end{array}$ & 1.076 & $\begin{array}{l}11.6633 \\
(0.0200)\end{array}$ & $\begin{array}{l}22.5315 \\
(0.3124)\end{array}$ \\
\hline 3 & $\begin{array}{c}0.6344 \\
(0.7282)\end{array}$ & -2.6529 & $\begin{array}{l}10.417 \\
(0.000)\end{array}$ & 1.332 & $\begin{array}{c}6.2741 \\
(0.1796)\end{array}$ & $\begin{array}{c}26.6982 \\
(0.1440)\end{array}$ \\
\hline
\end{tabular}

Source: Authors' calculations.

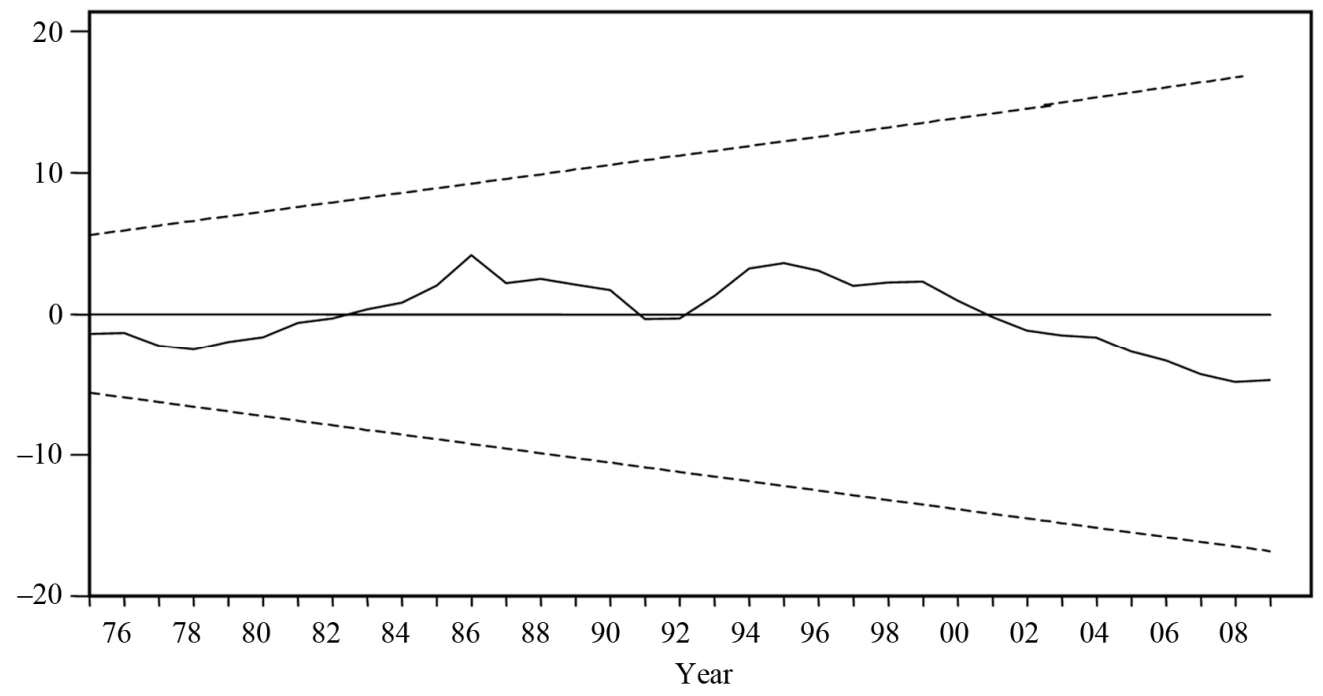

a. The straight broken lines represent critical bounds at the $5 \%$ significance level.

Figure 1. Cumulative sum of recursive residuals: model with $C P S^{\mathrm{a}}$. 


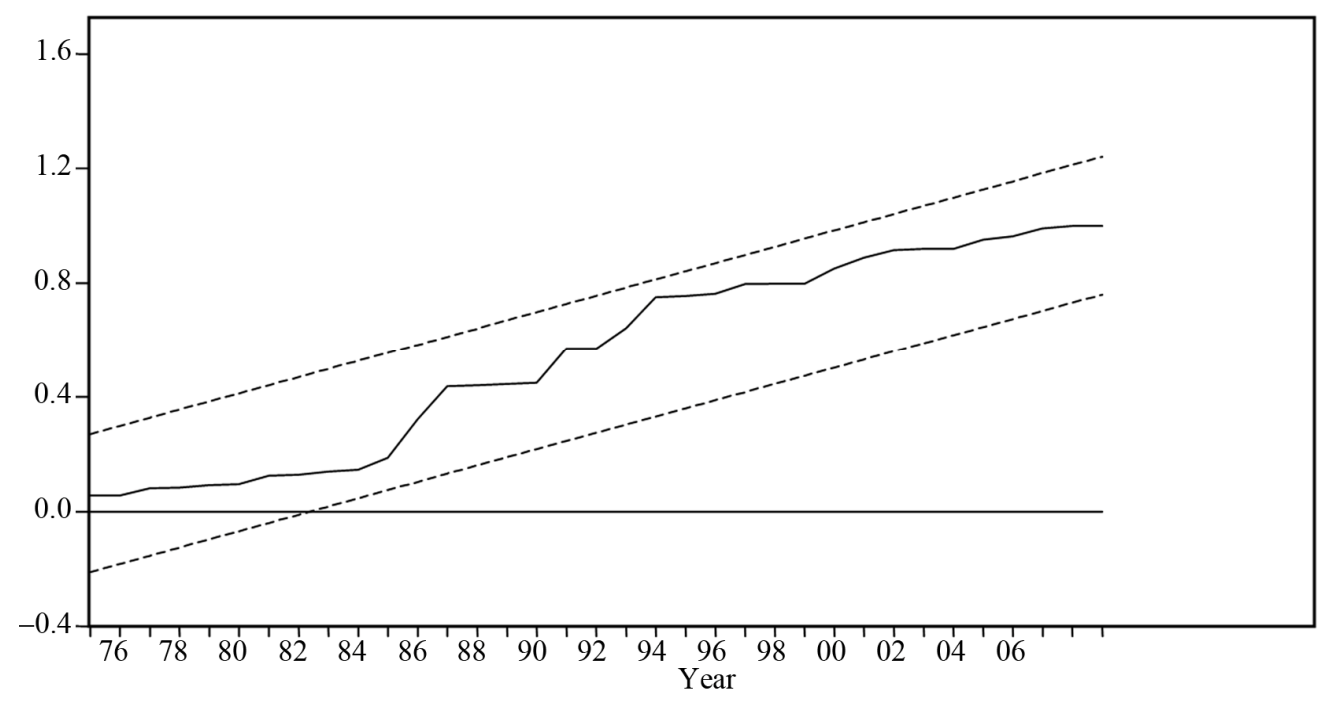

a. The straight broken lines represent critical bounds at the $5 \%$ significance level.

Figure 2. Cumulative sum of squares of recursive residuals: model with $C^{2} S^{\mathrm{a}}$

Table 5. Estimation of the short-run dynamic coefficients of the error correction representations of the $A R D L$ models: Dependent variable $\triangle \ln R G D P$.

\begin{tabular}{|c|c|c|c|c|c|c|c|c|}
\hline Regressor & Coeff. & t-Ratio & $\begin{array}{c}\text { Signific } \\
\text { Level }\end{array}$ & $R^{2}$ & $\begin{array}{c}\text { Adj } \\
R^{2}\end{array}$ & $A I C$ & $D W$ & F-Statistic \\
\hline Constant & -0.036 & -1.898 & 0.067 & & & & & \\
\hline$\Delta \ln R I N V$ & 0.135 & 3.684 & 0.001 & & & & & \\
\hline$\Delta \ln G$ & 0.079 & 1.570 & 0.126 & & & & & \\
\hline$\Delta \ln H$ & 0.180 & 1.095 & 0.281 & 0.601 & 0.528 & -2.896 & 1.392 & 9.038 \\
\hline$\triangle \ln O P E N$ & 0.177 & 1.586 & 0.122 & & & & & \\
\hline$\Delta \ln L I Q_{-1}$ & -0.088 & -1.566 & 0.127 & & & & & \\
\hline$E C_{t-1}$ & -0.470 & -3.077 & 0.004 & & & & & \\
\hline Constant & -0.001 & -0.011 & 0.991 & & & & & \\
\hline$\Delta \ln R I N V$ & 0.144 & 4.259 & 0.000 & & & & & \\
\hline$\Delta \ln G$ & 0.086 & 1.873 & 0.070 & & & & & \\
\hline$\Delta \ln H$ & 0.203 & 1.347 & 0.187 & 0.658 & 0.595 & -3.059 & 1.544 & 11.544 \\
\hline$\triangle \ln O P E N$ & 0.137 & 1.339 & 0.190 & & & & & \\
\hline$\Delta \ln M G D P_{-1}$ & -0.106 & -1.960 & 0.059 & & & & & \\
\hline$E C_{t-1}$ & -0.492 & -3.496 & 0.001 & & & & & \\
\hline Constant & 0.002 & 0.126 & 0.900 & & & & & \\
\hline$\Delta \ln R I N V$ & 0.148 & 5.029 & 0.000 & & & & & \\
\hline$\Delta \ln G$ & 0.050 & 1.308 & 0.200 & & & & & \\
\hline$\Delta \ln H$ & 0.186 & 1.320 & 0.196 & 0.703 & 0.649 & -3.201 & 1.548 & 14.202 \\
\hline$\triangle \ln O P E N$ & 0.131 & 1.384 & 0.176 & & & & & \\
\hline$\Delta \ln C P S_{-1}$ & -0.117 & -3.259 & 0.003 & & & & & \\
\hline$E C_{t-1}$ & -0.613 & -4.099 & 0.000 & & & & & \\
\hline
\end{tabular}

Source: Own calculations.

have become less statistically significant and have relatively lower impact on growth in the short run compared to the long-run. Similar to the long-run analysis, financial development seems to have significant negative impact on economic growth in the short run as well. The results also indicate that the coefficient of the error correction term, $E C_{t-1}$ has the right sign (negative) and is statisticcally significant, thereby confirming the existence of a stable long-run equilibrium (co-integrating) relationship between real GDP and its determinants for Saudi Arabia. The value of the coefficient of the error correction term, $E C_{t-1}$ implies a fairly high speed of adjustment to long-run equilibrium after a short-run shock. In particular, a deviation from the long-run equilibrium following a short-run shock is corrected by about 61.3 percent in a subsequent year. 


\section{Conclusion}

This paper employed the ARDL bounds testing approach to cointegration to examine the long and short run relationships between real GDP and financial development for Saudi Arabia using annual time series data during 1968-2010. The bounds test suggested that the variables of interest are bound together in the long-run. The results suggest that capital investment, government expenditure, human capital and trade openness are important determinants of long run economic growth in Saudi Arabia. In contrast, there is evidence that financial intermediation has exerted a significant negative impact on real GDP. This is attributed partly to the structure of the Saudi's economy and partly to the characteristic features of the Saudi's financial system. The high dependence of the economy on oil, together with the dominant role of the public sector in the economy leaves little room for the private sector to play a significant role in the economy. As such, we observe poor quality and high inefficiency in the allocation of bank credit, whereby less productive sectors receive a bigger share in such credit. In addition, the banking sector is plagued by weak competition, low levels of financial deepening, and lack of personnel with sufficient expertise in credit analysis. Banks also suffer from the lack of financial innovation, particularly with regard to Islamic financial products. The measures that are currently being taken towards privatization and economic liberalization are expected to provide real opportunities for the private sector to play a more positive role in economic activity, particularly in economic diversifycation. This could also provide a stimulus for the banking sector, which will hopefully be driven onto financing real growth, particularly in the industrial and agricultural sectors of the economy. Finally, the associated equilibrium correction was also significant confirming the existence of long-run relationships. The correction (adjustment) to equilibrium is fairly fast in that a deviation from the long-run equilibrium following a short-run shock is corrected by about 61.3 percent in a subsequent year.

\section{Acknowledgements}

I am grateful to Sheikh Mohamed Al-Fawzan Chair of Saudi's Macroeconomic Expectations at Al-Imam Muhammad Ibn Saud Islamic University, Riyadh, KSA, for providing the research fund in the year 2011. Thanks are also extended to Professor Khalid Meshall and Dr. Abdel Rahman Alsultan of the Department of Economics, for the discussion we have had on the Saudi's financial sector.

\section{REFERENCES}

[1] R. Levine, "Financial Development and Growth: Views and Agenda," Journal of Economic Literature, Vol. 35,
No. 2, 1997, pp. 688-726.

[2] M. Thiel, "Finance and Economic Growth: A Review of Theory and the Available Evidence," European Commission, Brussels, 2001.

[3] P. Wachtel, "Growth and Finance: What Do We Know and How Do We Know It?" International Finance, Vol. 4, No. 3, 2001, pp. 335-362. doi:10.1111/1468-2362.00077

[4] R. W. Goldsmith, "Financial Structure and Development," Yale University Press, New Haven, 1969.

[5] R. I. McKinnon, "Money and Capital in Economic Development," The Brookings Institute, Washington, 1973.

[6] E. S. Shaw, "Financial Deepening in Economic Development," Oxford University Press, New York, 1973.

[7] R. King and R. Levine, "Finance and Growth: Schumpeter Might Be Right," Quarterly Journal of Economics, Vol. 153, No. 3, 1993, pp. 717-738. doi:10.2307/2118406

[8] R. King and R. Levine, "Finance, Entrepreneurship, and Growth: Theory and Evidence," Journal of Monetary Economics, Vol. 32, No. 3, 1993, pp. 513-542. doi:10.1016/0304-3932(93)90028-E

[9] J. De Gregorio and P. Guidotti, "Financial Development and Economic Growth," World Development, Vol. 23, No. 12, 1995, pp. 433-438. doi:10.1016/0305-750X(94)00132-I

[10] A. Lanyi and R. Saracoglu, "The Importance of Interest Rates in Developing Countries," Finance and Development, Vol. 20, No. 2, 1983, pp. 20-23.

[11] N. Roubini and X. Sala-i-Martin, "Financial Repression and Economic Growth," Journal of Development Economics, Vol. 39, No. 1, 1992, pp. 5-30. doi:10.1016/0304-3878(92)90055-E

[12] J. Greenwood and B. Jovanovic, "Financial Development, Growth, and the Distribution of Income," Journal of Political Economy, Vol. 98, No. 5, 1990, pp. 1076-1107. doi: $10.1086 / 261720$

[13] G. Saint-Paul, "Technological Choice, Financial Markets, and Economic Development," European Economic Review, Vol. 36, No. 4, 1992, pp. 763-781. doi:10.1016/0014-2921(92)90056-3

[14] V. R. Bencivenga and B. D. Smith, "Financial Intermediation and Endogenous Growth," Review of Economic Studies, Vol. 58, No. 2, 1991, pp. 195-209. doi: $10.2307 / 2297964$

[15] T. Jappelli and M. Pagano, "Savings, Growth and Liquidity Constraints," Quarterly Journal of Economics, Vol. 109, 1994, pp. 83-109. doi:10.2307/2118429

[16] M. O. Odedokun, “Alternative Econometric Approaches for Analyzing the Role of the Financial Sector in Economic Growth: Time-Series Evidence from LDCs," Journal of Development Economics, Vol. 50, No. 1, 1996, pp. 119-135.

[17] R. Levine, N. Loayza and T. Beck, "Financial Intermediation and Growth: Causality and Causes," Journal of Monetary Economics, Vol. 46, No. 1, 2000, pp. 31-77. doi:10.1016/S0304-3932(00)00017-9

[18] C. Calderon and L. Liu, "The Direction of Causality between Financial Development and Economic Growth," 
Journal of Development Economics, Vol. 72, No. 1, 2003 , pp. 321-334.

[19] D. K. Christopoulos and E. G. Tsionas, "Financial Development and Economic Growth: Evidence from Panel Unit Root and Cointegration Tests," Journal of Development Economics, Vol. 73, No. 1, 2004, pp. 55-74. doi:10.1016/j.jdeveco.2003.03.002

[20] S. C. Valverde, R. L. del Paso and F. R. Fernández, "Banks, Financial Innovations and Regional Growth," Working Paper No. 04-34, Department of Economics, University of Granada, Granada, 2004.

[21] J. Z. Shan, "Does Financial Development 'Lead' Economic Growth? A Vector Auto-Regression Appraisal," Applied Economics, Vol. 37, No. 12, 2005, pp. 1353-1367. doi: $10.1080 / 00036840500118762$

[22] H. Zang and Y. C. Kim, "Does Financial Development Precede Growth? Robinson and Lucas Might Be Right," Applied Economic Letters, Vol. 14, No. 1, 2007, pp. 1519. doi:10.1080/13504850500425469

[23] J. E. U. Ndebbio, "Financial Deepening, Economic Growth and Development: Evidence from Selected Sub-Saharan African Countries," AERC Research Paper 142, Nairobi, 2004.

[24] S. Abu-Bader and A. Abu-Qarn, "Financial Development and Economic Growth: The Egyptian Experience," Journal of Policy Modeling, Vol. 30, No. 4, 2008, pp. 887-898. doi:10.1016/j.jpolmod.2007.02.001

[25] S. E. Mohamed and M. Sidiropoulos, "Finance-Growth Nexus in Sudan: Empirical Assessment Based on an Application of the Autoregressive Distributed Lag (ARDL) Model," Working Paper, BETA-Theme, University of Strasbourg, 2006.

[26] A. Al-Hassan, M. Khamis and N. Oulidi, "The GCC Banking Sector: Topography and Analysis," IMF Working Paper No. WP/10/87, International Monetary Fund, Washington DC, 2010.

[27] Saudi Arabian Monetary Authority, Forty Sixth Annual Report, Riyadh, 2010.

[28] R. T. Ariss, R. Rezvanian and S. M. Mehdian, "Cost Efficiency, Technological Progress and Productivity Growth of Banks in GCC Countries," International Journal of Business, Vol. 12, No. 4, 2007, pp. 471-487.

[29] D. S. Allen and L. Ndikumana, "Financial Intermediation and Economic Growth in Southern Africa," Federal Reserve Bank of St. Louis, Working Paper 1998-004B, 1998.

[30] P. L. Rousseau and P. Wachtel, "Financial Intermediation and Economic Performance: Historical Evidence from Industrial Countries," Journal of Money, Credit, and Banking, Vol. 30, No. 4, 1998, pp. 657-678.

\section{doi: $10.2307 / 2601123$}

[31] T. Beck, A. Demirguc-Kunt, R. Levine and V. Maksimovic, "Financial Structure and Economic Development: Firm, Industry, and Country Evidence," World Bank Working Paper No. 2423, 2000.

[32] World Bank, "Finance for Growth," World Bank, Washington DC, 2001.

[33] R. Levine and S. Zervos, "Stock Markets, Banks, and Economic Growth," American Economic Review, Vol. 88, No. 3, 1998, pp. 537-558.

[34] R. Levine and D. Renelt, "A Sensitivity Analysis of Cross-Country Growth Regressions," American Economic Review, Vol. 82, No. 4, 1992, pp. 942-963.

[35] W. R. Easterly and S. Rebelo, "Fiscal Policy and Economic Growth: An Empirical Investigation," Journal of Monetary Economics, Vol. 32, No. 3, 1993, pp. 417-457. doi:10.1016/0304-3932(93)90025-B

[36] S. Fischer, "The Role of Macroeconomic Factors in Growth," Journal of Monetary Economics, Vol. 32, No. 3, 1993, pp. 485-512.

[37] M. H. Pesaran, Y. Shin and R. J. Smith, "Bounds Testing Approaches to the Analysis of Level Relationships," Journal of Applied Econometrics, Vol. 16, No. 3, 2001, pp. 289-326. doi:10.1002/jae.616

[38] M. H. Pesaran and Y. Shin, "An Autoregressive Distributed Lag Modeling Approach to Cointegration, Chapter 11, in Econometrics and Economic Theory in the 20th Century," The Ragnar Frisch Centennial Symposium, Cambridge University Press, 1999.

[39] M. H. Pesaran and R. J. Smith, "Estimating Long-Run Relationships from Dynamic Heterogeneous Panels," Journal of Econometrics, Vol. 68, No. 1, 1995, pp. 79113. doi:10.1016/0304-4076(94)01644-F

[40] R. F. Engle and C. W. J. Granger, "Co-Integration and Error Correction: Representation, Estimation and Testing," Econometrica, Vol. 55, No. 2, 1987, pp. 251-276. doi: $10.2307 / 1913236$

[41] S. Johansen, "Statistical Analysis of Cointegrating Vectors," Journal of Economic Dynamics and Control, Vol. 12, No. 2-3, 1988, pp. 231-254. doi:10.1016/0165-1889(88)90041-3

[42] S. Johansen and K. Juselius, "Maximum Likelihood Estimation and Inference on Cointegration with Application to the Demand for Money," Oxford Bulletin of Economics and Statistics, Vol. 52, No. 2, 1990, pp. 169-210. doi:10.1111/j.1468-0084.1990.mp52002003.x

[43] M. H. Pesaran and B. Pesaran, "Working with Microfit 4.0: Interactive Econometric Analysis," Oxford University Press, Oxford, 1997. 